\title{
Infiltration and sedimentary brines of the Tunguska artesian basin and their chemical composition
}

\author{
Evgeniya Sidkina ${ }^{1, *}$ \\ ${ }^{1}$ Vernadsky Institute of Geochemistry and Analytical Chemistry, Russian Academy of Sciences \\ Sciences, 119991 Kosygin st., 19, Russia
}

\begin{abstract}
The paper presents shortly characterized types of brines by origin. Brines of the Tunguska artesian basin are devided into the following types: infiltration, sedimentary and ancient infiltration ones. For this classification, the calculation of genetic coefficients was used. The relationships between the origin of brines and their salinity and chemical composition are shown.
\end{abstract}

\section{Introduction}

Underground brines of the Tunguska artesian basin (AB) are unique highly salt solutions. The origin of these brines was studied by many researches [1-12]. This article provides new original data combined with previous publish data to show different origin of various types of brines. The task of the work is to determine the genetic types of brines and the geochemical features inherent in these types.

\section{Factual data}

219 determinations of the chemical composition of brines were processed (TDS, $\mathrm{Cl}^{-}, \mathrm{SO}_{4}{ }^{2-}$, $\mathrm{CO}_{3}{ }^{-}, \mathrm{Ca}^{2+}, \mathrm{Mg}^{2+}, \mathrm{Na}^{+}, \mathrm{K}^{+}, \mathrm{Br}^{-}, \mathrm{Sr}^{2+}, \mathrm{SO}_{2}$ ). Underground brines widespread over the all region. Brines from different parts of Tunguska $\mathrm{AB}$ were sampled from a depth of $500 \mathrm{~m}$ and deeper from Riphean, Vendian, Cambrian, Ordovician, Silurian, Permian, and Triassic host rocks [3-7, 10-12]. According to hydrogeological stratification, the whole sedimentary cover is divided into suprasalt, salt and subsalt formations [4]. For comparison, 104 brine samples from the Olenek $\mathrm{AB}$ of the Upper Cambrian and Vendian-Middle Cambrian complexes were taken into consideration [1-2].

\section{Genetic coefficients and metamorphism of brines}

Natural brines are divided into two genetic types: infiltration and sedimentary. The chemical composition of infiltration brines is related to the dissolution of halogenic rocks.

\footnotetext{
*Corresponding author: SidkinaES@yandex.ru
} 
Thus, the solvent (water) and solutes in such brines have different origin and age. The composition of sedimentary brines is governed by the halogenic basin-hosted seawater, which was formed in the course of evaporative concentration and eventually buried together with the host rocks. The buried seawater was subjected to significant geochemical metamorphism during geological evolution $[8-9,13]$.

The criteria for the separation of brines are based on the ratios of $\mathrm{Cl} / \mathrm{Br}$ and $\mathrm{rNa} / \mathrm{rCl}$ in seawater during the halite stage. According to [14] ratios $\mathrm{Cl} / \mathrm{Br}$ and $\mathrm{rNa} / \mathrm{rCl}$ are respectively 326 and $0.79-0.82$ at the start of halite precipitation. Brine salinity is 275.27 (stage start) $320 \mathrm{~g} / \mathrm{dm}^{3}$ (end of precipitation) [9]. These limits permit natural brines to be divided into types. During progress of metamorphism of brines, contents of calcium, strontium and bromine increase. Bromine content grows mainly due to concentrating of seawater (evaporation) and precipitation of halite, which is depleted of bromine relative to the brine [15]. Contents of calcium and strontium increase by the interaction of brines with host rocks.

Genetic and metamorphic coefficients for both Tunguska and Olenek basins are shown in Table 1. Information on metamorphic coefficients is described in the paper [8]. In the Tunguska $\mathrm{AB}$, infiltration brines are found mainly within the suprasalt formation: Triassic, Permian, Carboniferous, and less common Devonian and Silurian rocks. Brines have low TDS values (less than $200 \mathrm{~g} / \mathrm{dm}^{3}$ ), sodium chloride composition, and low contents of microcomponents. These infiltration solutions are characterized by low metamorphic coefficients.

Table 1. Genetic and metamorphic coefficients of brines in the Tunguska and Olenek artesian basins.

\begin{tabular}{|c|c|c|c|c|c|c|}
\hline & $\begin{array}{c}\text { Genesis and } \\
\text { hydrogeological } \\
\text { formation }\end{array}$ & $\begin{array}{l}\text { TDS, } \\
\text { g/dm }\end{array}$ & $\mathrm{Cl} / \mathrm{Br}$ & $\mathrm{rNa} / \mathrm{rCl}$ & $\mathrm{Ca} / \mathrm{Cl}$ & $\mathrm{Sr} /\left(\mathrm{Cl}^{*} 10^{-3}\right)$ \\
\hline \multirow{3}{*}{ 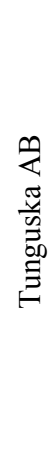 } & $\begin{array}{c}\text { Infiltrational } \\
\text { (Suprasalt formation) }\end{array}$ & $\frac{41-196}{89(26)}$ & $\frac{471-2696}{1218}$ & $\frac{0.72-1.02}{0.95}$ & $\frac{0.01-0.15}{0.04}$ & $\frac{0.16-9.41}{1.19}$ \\
\hline & $\begin{array}{c}\text { Sedimentary } \\
\text { (Suprasalt, Salt, } \\
\text { Subsalt } \\
\text { formations) }\end{array}$ & $\frac{255-528}{356(181)}$ & $\frac{30-293}{68}$ & $\frac{0.05-0.70}{0.30}$ & $\frac{0.10-0.53}{0.30}$ & $\frac{1.31-25.91}{8.77}$ \\
\hline & $\begin{array}{c}\text { ancient } \\
\text { infiltrational } \\
\text { (Subsalt formation) } \\
\end{array}$ & $\frac{112-281}{222(14)}$ & $\frac{335-521}{404}$ & $\frac{0.50-0.90}{0.75}$ & $\frac{0.04-0.25}{0.10}$ & $\frac{0.05-8.50}{3.00}$ \\
\hline $\begin{array}{l}\frac{9}{4} \\
\frac{4}{0} \\
\frac{0}{0}\end{array}$ & $\begin{array}{c}\text { Sedimentary } \\
\text { (Upper Cambrian } \\
\text { and Vendian-- } \\
\text { Middle } \\
\text { Cambrian } \\
\text { complexes) }\end{array}$ & $\frac{40-425}{233(104)}$ & $\frac{39-162}{55}$ & $\frac{0.09-0.34}{0.19}$ & $\frac{0.18-0.38}{0.29}$ & $\frac{0.61-12.00}{5.62}$ \\
\hline
\end{tabular}

The salt formation of Tunguska $\mathrm{AB}$ contains sedimentary brines only, and suprasalt and subsalt formation contains both sedimentary and infiltration brines. In the suprasalt formation of the Tunguska AB, sedimentary brines are located mainly in the northwestern part, which belong to the continuous permafrost rock zone. All studied brines of the Olenek $\mathrm{AB}$ are also sedimentary. Pure sedimentary brines are characterized by high TDS and calcium chloride composition with high contents of $\mathrm{Br}, \mathrm{Sr}, \mathrm{Li}$, and other microcomponents. 
Usually, the TDS of the studied samples of sedimentary brines is higher than $320 \mathrm{~g} / \mathrm{dm}^{3}$ (halite precipitation stage) and reaches $500 \mathrm{~g} / \mathrm{dm}^{3}$ or higher in some places. The correlation of metamorphic coefficients to the brine TDS is shown in fig. 1. The seawater concentration curve is plotted according to [9].

The subsalt formation also includes ancient infiltration brines (Table 1). Such brines are assigned to the infiltration type $(\mathrm{Cl} / \mathrm{Br} 335-521, \mathrm{rNa} / \mathrm{rCl} \quad 0.5-0.9)$, but they are characterized by high contents of $\mathrm{Ca}, \mathrm{Mg}$, and microcomponents. Based on the genetic coefficients, such brines may be considered as solutions of the continental origin. However, due to prolonged interaction with host rocks and, probably, mixing with marine salt waters, they are highly mineralized and considerably metamorphosed [4].

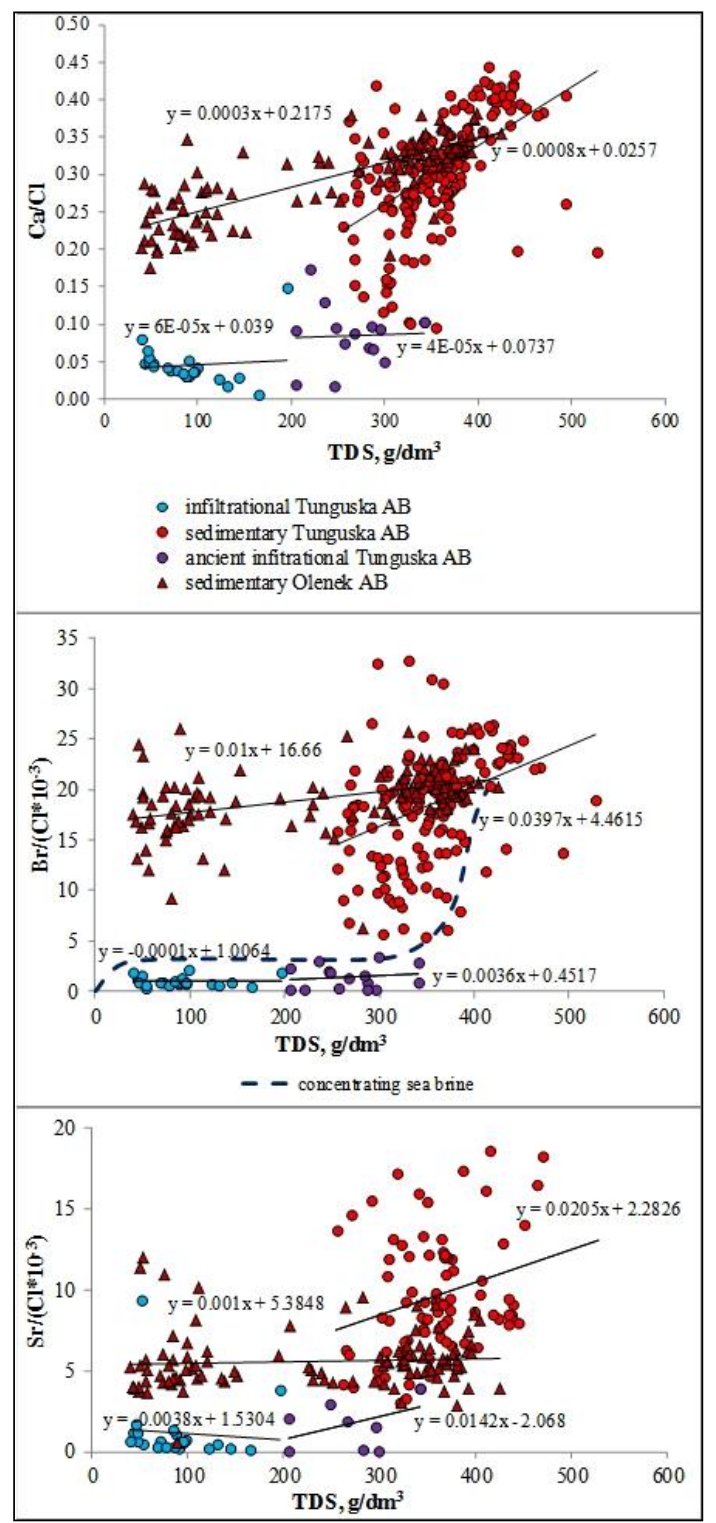

Fig. 1. The correlation of metamorphic coefficients to the brine TDS. 
We also calculated the degree of solution saturation with respect to the most common minerals. Activities of the solutes of brines were calculated using Pitzer model [16]. It was found that sedimentary brines were saturated with respect to carbonates, sulfate, and secondary aluminosilicate minerals, such as (illite, montmorillonites, kaolinite, muscovite, and others). Thermodynamic calculations show that some samples of sedimentary solutions are saturated with respect to halite. Infiltration brines are undersaturated with all minerals except gibbsite [17]. Ancient infiltration brines have a higher degree of saturation than modern ones. This shows that the origin and duration of interaction with rocks are the main factors of formation of the chemical composition of brines.

\section{Conclusions}

Natural brines of Tunguska $\mathrm{AB}$ divided into infiltration, sedimentary and ancient infiltration by calculating genetic coefficients. Infiltration brines of Tunguska $A B$ are sodium chloride ones and have TDS less than $200 \mathrm{~g} / \mathrm{dm}^{3}$, low contents of microcomponents. Infiltration brines are undersaturated with minerals other than gibbsite. Sedimentary brines are characterized by high TDS and calcium chloride composition with high contents of $\mathrm{Br}, \mathrm{Sr}, \mathrm{Li}$, and other microcomponents. Ancient infiltration brines will be a subject for study in future research.

\section{References}

1. S.V. Alekseev, Cryohydrogeological Systems of the Yakutian Diamond Province (Geo, Novosibirsk, 2009)

2. S.V. Alekseev, L.P. Alekseeva, S.L. Shvartsev, N.S. Trifonov, E.S. Sidkina, Geochem. Int., 55, 442-456 (2017)

3. E.A. Baskov, Mineral Waters and Paleohydrogeology of the Siberian Platform (Moscow: Nedra, 1977)

4. M.B. Bukaty, Russ. Geol. Geophys., 50, 1201-1217 (2009)

5. L.N. Kapchenko, Tr. VNIIGRI, 396, 7-18 (1977)

6. E.V. Pinneker, Brines in the Angara-Lena Artesian Basin (Moscow: Nauka, 1966)

7. S.L. Shvartsev, Geol. Geofiz., 6, 23-30 (1973)

8. S.L. Shvartsev, , Geochem. Int., 38, 1070-1083 (2000)

9. M.G. Valyashko, Geochemical Regularities in the Formation of Potassium Salt Deposits (Moscow: MGU, 1962)

10. V.I. Vozhov, Groundwaters and Hydromineral Resources in the Lena-Tunguska PetroliferousProvince (Novosibirsk: SNIIGGiMS, 2006)

11. I.K. Zaitsev, Hydrogechemistry of the Soviet Union (Leningrad: Nedra, 1986)

12. I.K. Zaitsev, E.A. Baskov, Tr. VSEGEI, 46, 5-45 (1961)

13. S.R. Kraynov, B.N. Ryzhenko, V.M. Shvets Geochemistry of ground waters (Moscow: Nauka, 2004)

14. P. Sonnenfeld, Brines and Evaporites (Academic Press, INC, 1984)

15. A.B. Carpenter, Circl. Oklahoma Geol. Surve,. 79, 60 - 77 (1978)

16. K.S. Pitzer, Reviews in Mineral, 17, 97 - 142 (1987)

17. E.S. Sidkina, Lithol. and Miner. Resour., 53, 252 - 262 (2018) 